\title{
СПЕЦИФІКА РЕАЛІЗАЦІЇ ПРИНЦИПУ НАСТУПНОСТІ В НАВЧАННІ ДІТЕЙ ДОШКІЛЬНОГО І МОЛОДШОГО ШКІЛЬНОГО ВІКУ
}

Ковшар О. В. Специфіка реалізації принципу наступності в навчанні дітей дошкільного і молодшого шкільного віку.

В статті визначено поняття наступності, окреслено поняття готовності до навчання дітей дошкільного віку, висвітлено роль наступності в організації освіти, розглянуто готовність в соціальному, психологічному, інтелектуальному плані, розкрито значення швидкої адаптації дітей до навчання в школі.

Ключові слова: адаптація до навчання, наступність, наступність у навчанні, готовність до навчання у школі.

В статье дано определение понятия преемственность, очерчено понятие готовности к обучению детей дошкольного возраста, раскрыта роль преемственности в организации образования, рассмотрена готовность к обучению в школе в социальном, психологическом, физическом, интеллектуальном плане, раскрыто значение быстрой адаптации детей к обучению в школе.

Ключевые слова: адаптация к обучению, преемственность, преемственность в обучении, готовность к обучению.

Kovshar O. V. Specificity of the principle of continuity in teaching of children of preschool and primary school age.

The article defines the notion of continuity. It outlines the concept of readiness for teaching preschool children. The role of continuity in organization of education is revealed. The article deals with readiness in social, psychological and intellectual terms. The rapid adaptation of children to learning at school is illustrated.

Key words: adaptation to learning, continuity, continuity in studying, readiness to learning at school.

Проблема наступності між дошкільною та початковою ланками є нині надзвичайно складною, значущою й актуальною. 3 ії розв'язанням фахівці пов'язують успішність реформування не тільки перших двох ланок загальної освіти, але й усієї освітньої системи.

Проблема наступності характеризується об'єктивним і всезагальним характером, маючи своє відображення у суспільстві, природі та пізнанні. У кожній окремій галузі вона має конкретний зміст, який виявляє свої особливості. Так, «Базовий компонент дошкільної освіти» (1998р.), «Державний стандарт початкової загальної освіти» (2000р.), доповнення до Базового компоненту дошкільної освіти $(2012$ р.) «Закон про дошкільну освіту» (2001р.), Державна національна програма «Освіта» (Україна XXI століття), «Національна доктрина розвитку освіти України у XXI столітті», Закон «Про дошкільну освіту», «Про охорону дитинства», Державна цільова програма розвитку дошкільної освіти на період до 2017 р., наголошує про необхідність наукового забезпечення модернізаціі дошкільної освіти, спрямовує освітян на оновлення життєдіяльності дітей дошкільного та молодшого шкільного віку, створює умови для їхньої самореалізації та самоствердження.

Стосовно завдань дошкільної й початкової освіти академік А. Богуш зазначає: «Створити для дитини комфортне життя означає забезпечити для неї змістове в усьому його розмаїтті емоційно насичене, позитивно забарвлене життя на всіх сходинках соціальних осередків: у сім'ї, у дошкільному закладі, у школі і соціумі» [2, с 11]. Нині пріоритетним напрямом відбудови системи дошкільної освіти є створення умов для забезпечення рівного стартового рівня дітей при вступі їх до школи. 
Основні причини утруднень в реалізації наступності в навчанні дошкільників та молодших школярів зумовлені такими чинниками:

- несистемний характер здійснення наступності в навчанні дітей дошкільного та молодшого шкільного віку, унаслідок чого - переважання функціонального підходу у визначенні мети, завдань, змісту наступності, а також шляхів іiї реалізації;

- $\quad$ відсутність індивідуального підходу до першокласників у період їхньої адаптації до навчання в школі.

- н низький рівень розробленості теоретичних і методологічних підходів до реалізації наступності в дошкільних закладах та початковій школі;

- недостатню наступність у діяльності дошкільних закладів і початкової школи у змісті освіти, використанні форм, методів і технологій навчання й виховання, діагностування дитини дошкільного та молодшого шкільного віку;

- недостатній рівень професійної компетентності педагогів дошкільних закладів і вчителів початкової школи у питаннях здійснення наступності і, як наслідок, гальмування в реальній освітній практиці процесу заміни функціонального підходу до розв'язання проблем наступності в навчанні дітей дошкільного та молодшого шкільного віку на педоцентричний.

Meта статmi - визначити особливості, структуру наступності в навчанні й окреслити шляхи подолання утруднень реалізації наступності між дошкільною та початковою освітою.

Стратегічна мета функціонування дошкільної та початкової ланок освіти полягає в цілісному розвитку особистості дитини, який забезпечується завдяки розвитку мотиваційної, пізнавальної, діяльнісно-практичної, емоційно-вольової підструктур. У цьому контексті, що стосується дошкільних освітніх закладів, наступність виявляється не тільки в підготовці до школи, але й у забезпеченні загального психічного розвитку дитини. Щодо початкової школи, то наступність передбачає продовження загального психічного розвитку дитини на основі максимального використання того, чого дитина набула в дошкільному віці і що є базою для іiї подальшого розвитку.

Отже, наступність - одна 3 основних умов системності навчання, основний принцип розвитку освіти .

Навчальна діяльність - це процес організації педагогом пізнавальної активності дітей задля засвоєння останніми програмових знань, умінь, навичок, а також способів діяльності. Структура навчальної діяльності передбачає навчальну діяльність педагога, спрямовану на організацію засвоєння дітьми певних знань, умінь і навичок та власну навчальну діяльність дітей, у процесі якої вони сприймають та засвоюють навчальний матеріал.

Наступність навчальної діяльності - це взаємозв'язок та узгодженість змісту, ступенів і етапів навчального процесу, методів, прийомів, форм його організації, за яких знання, уміння й навички формуються у певному порядку: коли наступний елемент навчального матеріалу, зв'язаний з попереднім, опирається на нього і готує до засвоєння нового.

Наступність навчальної діяльності в умовах дошкільної та шкільної освіти характеризується злагодженою роботою педагогів і взаємозв'язком провідних видів діяльності дітей старшого дошкільного та молодшого шкільного віку, спрямованих на їхній пізнавальний розвиток.

Проблема наступності своїми коренями пов'язана $з$ діалектичним законом заперечення заперечення, який було сформульовано Г. Гегелем на межі XVIII - XIX ст. У цьому законі розкрито діалектичну сутність розвитку, який трактується як процес, що спрямований не тільки на ліквідацію віджитого, але й на збереження і подальше вдосконалення того прогресивного, що було досягнуто на попередніх ступенях, без чого неможливе просунення вперед ні в бутті, ні в свідомості.

Важливою ознакою наступності навчальної діяльності в умовах дошкільної та шкільної ланок освіти є її структура, яка передбачає виокремити три етапи реалізації наступності в 
навчанні дошкільників та молодших школярів: 1 етап - забезпечення готовності дошкільників до навчання в школі; 2 етап - створення умов для найшвидшої адаптації дітей до шкільних умов; 3 етап - розвиток учнів початкової школи на основі надбань дошкільного дитинства та із застосуванням педагогічних технологій дошкільної освіти.

Виявимо специфіку реалізації принципу наступності в навчанні дітей дошкільного і молодшого шкільного віку на кожному з зазначених етапів.

1 етап - забезпечення готовності дошкільників до навчання в школі.

У психолого-педагогічній літературі готовність до школи трактується як загальна розвиненість особистості, що дозволяє дитині залучитись до систематичного процесу навчання та успішно засвоїти його зміст, як цілісна система властивостей і якостей, що повинен набути дошкільник у своєму фізичному, розумовому, естетичному, моральному розвитку. Рівень підготовки передбачає певний ступінь зрілості всього організму та нервової системи, завдяки чому дитина може справитися з підвищеними розумовими та фізичними навантаженнями. Крім того, суттєве значення має набутий запас елементарних знань про навколишній світ, найпростіші навички практичної та розумової діяльності, рівень розвитку мислення, мови та пізнавальних інтересів, рівень сформованості суспільних мотивів поведінки та морально-вольових якостей.

Для визначення поняття готовності старших дошкільників до навчальної діяльності звернемося до словника С. Гончаренка, де сказано: «Готовність до шкільного навчання сукупність морфофізіологічних i психологічних особливостей дитини старшого дошкільного віку, яка забезпечує успішний перехід до систематично організованого шкільного навчання» [4, с. 73]. Розв'язання проблеми готовності до навчання неможливе без розгляду іiі компонентів: «Психологічна готовність до школи - це цілісна, системна освіта: відставання в розвитку одного компонента тягне за собою перекручення в розвитку інших» [4, с. 110].

Г. Люблінська пропонує такі показники готовності дитини до школи:

1. Загальний фізичний розвиток дитини.

2. Володіння достатнім обсягом знань, умінь і навичок, а також зв'язною, граматично і фонетично правильною мовою.

3. Сформованість звичок і навичок поведінки.

4. Розвиток дрібної моторики руки.

5. Бажання вчитися, інтерес до знань, радість від пізнання нового .

Т. Кондратенко, В. Котирло, С. Ладивір визначили такі основні компоненти готовності до навчання: відповідний рівень оволодіння загальними способами пізнавальної діяльності: умінням аналізувати, порівнювати, узагальнювати; формування здібності до мимовільної регуляції своєї поведінки.

Особливості готовності дітей шестирічного віку до навчання у школі охарактеризовано I. Домашенко й доведено, що основна трудність для шестирічних дітей полягає у незнанні, як почати; як спрямувати мислення у відповідному напрямку. У цьому ж напрямку низку досліджень здійснили О. Аматьєва, О. Фунтікова, Г. Лаврентьєва, С. Кулачківська, С. Ладивір, Т. Піроженко, які в розвідках відобразили тенденції сучасних проблем готовності старших дошкільників до навчальної діяльності у школі. Так, Ле Тхань Ван досліджувала педагогічні умови формування функціональної готовності дітей старшого дошкільного віку до початку систематичного навчання в школі. Педагогічний експеримент автора показав, що процес адаптації відбувається значно легше за умови формування функціональної готовності організму дитини в різних видах діяльності: навчальній, ігровій, трудовій, образотворчій, практично-предметній.

Ця ідея дотримується Б. Волковим та Н. Волковою, які встановили, що для того, щоб підготувати дитину до навчання в школі, необхідно вміти: формувати у старшого дошкільника готовність і бажання навчатися, відповідно організовувати його життя $\mathrm{i}$ діяльність, співпрацювати з дітьми у різних видах діяльності; здійснювати індивідуальний 
підхід до дітей; контролювати психічний розвиток дітей 6-7 років, пропагувати психолого-педагогічні знання серед батьків.

Л. Божович уважає, що готовність до навчання в школі складається 3 певного рівня розвитку розумової діяльності та пізнавальних інтересів, готовності до довільної регуляції своєї пізнавальної діяльності та готовності до опанування соціальною позицією школяра . Більш лаконічно визначає шкільну зрілість I. Шванцара - як досягнення такого ступеня розвитку, коли дитина стає спроможною брати участь у шкільному навчанні. Науковець виокремлює розумовий, соціальний і емоційний компоненти готовності до навчання. А. Анастазі трактує поняття «шкільної зрілості» як опанування вмінь, знань, мотивації та інших необхідних для певного рівня засвоєння шкільної програми поведінкових характеристик.

Матеріали досліджень Є. Кравцової показують, що готовність до шкільного навчання має комплексний характер. Однак структурування цієї готовності відбувається не шляхом диференціації загального психічного розвитку дитини на інтелектуальну, емоційну та ін. сфери, а отже, види готовності. Вона виокремлює компоненти психологічної готовності дітей до навчання в школі на основі розгляду системи взаємовідношень дитини 3 навколишнім світом у трьох сферах: ставлення до дорослого, до однолітків, самого себе.

Як свідчать результати дослідження С. Громбах, готовність дитини до школи визначається іï фізичним і психічним розвитком, станом здоров'я, розумовим i особистісним розвитком. Притому значення має весь комплекс чинників. Тому прийнято вважати, що готовність до систематичного навчання в школі («шкільна зрілість») - це той рівень морфологічного, функціонального і психічного розвитку дитини, за умов якого вимоги систематичного навчання не виявляться надмірними та не призведуть до погіршення здоров'я дитини. При цьому психологічна готовність до навчання розглядається як комплекс морально-психологічних особливостей, у якому мотиваційний аспект, як внутрішня спонука, є основним. На це звертає увагу О. Венгер, зауважуючи, що психологічна підготовка до шкільного навчання складається 3 мотиваційної, вольової і розумової готовності та готовності у сфері взаємовідносин. Мотиваційна готовність - це насамперед прагнення до нової для дитини діяльності - навчання. Вона позначається на вольовій і розумовій діяльності. Вольова готовність до навчання виявляється у здатності сприймати, запам'ятовувати і відтворювати навчальні дії, підпорядковувати ігрові та інші мотиви навчальним, у наполегливості й доведенні до успішного завершення навчальних, трудових та інших доручень. Розумова готовність до навчання полягає в умінні володіти диференційованим сприйманням, елементарними формами смислового запам'ятовування, логічного мислення, відтворюючою уявою [3, с. 34].

Рівень розвитку психологічної готовності до навчання має індивідуальний характер, залежить від особливостей розвитку механізмів психічної діяльності дитини та умов іiі виховання.

Навчання в школі - своєрідна діяльність. Як і трудова, вона висуває до дитини низку вимог. Щоб успішно вчитись, треба бути дисциплінованим, додержуватись правил поведінки, засвоювати знання, набувати умінь і навичок. Навчання - результативна діяльність, що оцінюється, як і наслідки продуктивної трудової діяльності, потребує великого напруження фізичних і особливо розумових сил дитини. К.Ушинський визначав, що навчання - це праця і має лишатися працею, але працею, сповненої думки, щоб інтерес до навчання залежав від серйозності думки, а не якихось прикрас, що не стосуються справи.

На сучасному етапі розвитку школи психологічна готовність дітей до навчання набуває особливого значення. Підвищуються вимоги до пізнавальних здібностей дитини, до іiі теоретичних знань, висуваються нові вимоги до формування в учнів прийомів самостійного мислення. Програмний матеріал уже в першому класі побудовано так, що його засвоєння потребує значного розвитку спостережливості, розумової діяльності. 
Перебудова навчання у школі зумовлена необхідністю активізувати розумову діяльність дитини. Цьому сприяє насиченість навчального матеріалу з мови, математики в початкових класах новими термінами й поняттями. Як показують дослідження психологів (Л. Занкова, Д. Ельконіна, В. Давидова та ін.), це підвищує рівень теоретичних знань і теоретичного мислення, ініціативи й самостійності у процесі розв'язування завдань, осмислення змісту навчання. О. Запорожець, Н. Сакуліна, М. Поддяков, О. Усова та ін. психологи i педагоги довели, що продуктивна діяльність дитини - малювання, конструювання, ліплення - сприяє їі розумовому розвитку тоді, коли вона проводиться цілеспрямовано, а не як гра. Під впливом таких занять дошкільник більш активно опановує сенсорну культуру, у нього успішніше формуються системи перцептивних дій, передумови для самостійного мислення.

2 етап - створення умов для швидкої адаптації дітей до шкільних умов.

Зі вступом дитини до школи перебудовуються основні установки, звички, спосіб ії життя, поведінка. Ставши школярем, вона бере на себе нові обов'язки, виконання яких потребує дисциплінованості, самовладання, відповідальності, достатнього розвиту вольових якостей, розсудливості, свідомого контролю бажань і прагнень. У дитини змінюється соціальна позиція: вона стає маленьким громадянином, який відповідає за успіхи у своєму навчанні. Отже, зі вступом дитини до школи в їі житті починається новий етап, ігрова діяльність змінюється навчальною. Процес адаптації до нових умов потребує значних духовних і фізичних сил дитини. У зв'язку з цим поряд із завданням забезпечення готовності дошкільників до навчання в школі другим, не менш важливим завданням під час реалізації наступності є завдання управління процесом адаптації дитини до школи. Адаптація (від лат. adaptatio) до навчання, згідно з визначенням у педагогічному словнику С. Гончаренка, - це пристосування, процес або результат процесу, який передбачає гармонійне, з позиції індивідуальних прагнень дитини, задоволення її потреб, створення умов для іï успішного навчання під час перебування в освітньому закладі [4].

Психологічні особливості дітей під час адаптації до навчальної діяльності було досліджено О. Боделан. Вона вважає, що системність у забезпеченні розвитку мотиваційних, комунікативних, інтелектуальних та емоційно-вольових особливостей досягається нетрадиційними засобами проведення різних занять як в умовах класу, так і в умовах реальної навчально-виховної діяльності. Це значно підвищує адаптацію учнів до навчання .

Успішна адаптація до навчальної діяльності першокласників можлива завдяки обгрунтуванню особливостей навчання молодших школярів. Визначення особливостей організації навчальної діяльності першокласників буде слугувати базисом, до якого слід прагнути й який необхідно враховувати у підготовці до навчання старших дошкільників.

Г. Бурменська, О. Карабанова та А. Лідерс виокремлюють психологічні труднощі власне молодшого шкільного віку, які негативно впливають на адаптацію дитини до школи. Вони зазначають, що ці труднощі є відображенням поступового входження дитини до нової соціальної ситуації розвитку: у неї з'являються «режимні» обов'язки - вчасно приходити до школи, приділяти час підготовці домашнього завдання, навіть усупереч власним потребам у грі та відпочинку. Відбувається процес адаптації до нового колективу однолітків. Започатковуються ділові й особистісні стосунки з учителем. I, нарешті, змінюється соціальна позиція дитини в сім'ї. Діти далеко не завжди з однаковою успішністю пристосовуються до нових умов життєдіяльності. Тому необхідною виявляється спеціально організована робота, спрямована на адаптацію першокласників до шкільних умов. Притому дошкільний заклад повинен розпочинати роботу з адаптації дитини до школи, а школа іiі продовжувати. Так, у дошкільному закладі доцільно формувати в майбутніх першокласників первинні уявлення про соціальну позицію «учня», навчальну діяльність, а в першому класі здійснювати плавний перехід від ігрової діяльності до навчання. Як бачимо, для сприятливої соціально-психологічної адаптації 
дитини до школи велике значення має наступність методів роботи та педагогічного спілкування педагогів дошкільного закладу та початкової школи.

3 етап - розвиток учнів початкової школи на основі надбань дошкільного дитинства та iз застосуванням педагогічних технологій дошкільної освіти

Важливе значення для осмислення питань щодо організації роботи на третьому етапі мають наукові погляди О.Запорожця про те, що підвищення ефективності реалізації принципу наступності в навчанні дітей можливе лише за умов урахування внутрішнього, органічного зв'язку загального фізичного та духовного розвитку на межі дошкільного та шкільного дитинства. 3 одного боку, це передбачає вдосконалення дошкільного виховання, спрямованість на вимоги, перспективність школи; з іншого, - повноцінний розвиток тих здобутків дошкілля, формування яких ще не завершилося на рівні дошкільного віку.

Наступність дошкільного навчального закладу і початкової школи передбачає опору в школі на знання, уміння, творчі якості і здібності, які дитина одержала у дитячому садку і така наступність між дошкільним навчальним закладом i початковою школою здійснюється, як за змістом, так і шляхом застосування методів, прийомів, організаційних форм. Ідея здійснювати навчальну діяльність першокласників, використовуючи активні методи навчання, підтримується багатьма педагогами і психологами: С. Архангельським, Б. Баєвим, Ф. Блехер, П. Блонським, Є. Бугріменко, Г. Цукерман, Д. Ельконіним, О. Киричук та ін. Ще С. Русова головним завданням навчання вважала пробудження інтересу до науки. Нецікава праця, на думку С. Русової, викликає інколи таку апатію, яку легко прийняти за втому, тому що відсутність усякого інтересу паралізує енергію, кожне зусилля учня.

Підвищення показників рівня готовності до школи, а також адаптація до навчання можливі завдяки взаємопереходу провідних видів діяльності дітей старшого дошкільного та молодшого шкільного віку: ігрової та навчальної.

Учителі початкової школи з метою підвищення ефективності навчання використовують найрізноманітніші ігрові методи і прийоми: відвідують заняття в дошкільних групах, ознайомлюються 3 картами розвитку дітей старшого дошкільного віку, складеними психологом та вихователями дошкільних груп, картами психічного розвитку дітей. Основною метою таких карт $є$ поглиблення і розширення знань педагога про дітей, які використовуються, 3 одного боку, для надання допомоги і підтримки кожної дитини 3 урахуванням іiі індивідуальних творчих особливостей; з іншого, - для визначення рівня ii готовності до навчання в школі. Адже готовність до школи охоплює різні сторони психічного розвитку дитини і повністю може бути визначеною тільки спеціалістомпсихологом. Але вихователь, який працює з дітьми дошкільного віку і аналізує їхню поведінку, доповнює спостереження психолога про відповідність чи невідповідність дитини, щодо стандарту віку, шляхом спостереження за дітьми, вивчення продуктів їх діяльності (малюнки, аплікації), за допомогою нескладних завдань.

Проблема навчання вивчала Л. Божович. Навчання у школі вона розглядала як самостійний вид діяльності, спеціально організований i спрямований на своє пряме завдання - систематичне засвоєння відповідної суми знань i навичок, передбачених шкільною програмою. Проведений Л. Божович аналіз показав: якщо заняття викликають у дітей інтерес, то вони швидко засвоюють програмний матеріал, порівняно легко виконують навчальні вправи, виявляють більшу творчу ініціативу.

Велику кількість робіт присвятив проблемі навчання дітей молодшого шкільного віку Ш. Амонашвілі. Він писав: «Якщо ми забудемо про те, що діти не можуть розлучитися зі своєю потребою гратися, то зробимо нашу методику не добрим путівником їх до світу пізнання, а бездушною мачухою» [1, с. 202]. У своїй роботі з дітьми він широко використовував ігрові моменти [1, с. 202-203], уважаючи їх необхідними у процесі навчанні та вказуючи при цьому, що дитина буде прагнути до уроків, якщо вона знайде в них умови для більш цікавого і стрімкого руху свого життя [1, с. 135]. 
Найважливішим показником розвитку дошкільника $є$ рівень оволодіння різними видами діяльності, що, з одного боку, є джерелом і рушійною силою розвитку, а 3 іншого боку галуззю прояву досягнень. Рівень розвитку будь-якого виду дитячої діяльності оцінюється двома найважливішими характеристиками: перша- це ступінь оволодіння діяльністю, другою характеристикою є рівень освоєння операціонально-технічної сторони діяльності, тобто оволодіння необхідними навичками. Крім виявлення досягнень дитини через аналіз освоєння нею конкретної діяльності необхідно знайти такі характеристики розвитку, у яких відбиваються найбільш істотні особистісні якості, перш за все, це розвиток рухової сфери, 3 особливо оволодіння руховими навичками. Рівень такого оволодіння надзвичайно показовий для оцінки загального розвитку дитини. Найважливішою сферою, що характеризує рівень готовності дитини у роботі навчального закладу $є$ соціальний розвиток, тобто ті якісні зміни, від яких залежить можливість жити в суспільстві, взаємодіяти з іншими людьми, дітьми і дорослими. Соціальний розвиток, насамперед, характеризується рівнем оволодіння дітьми різними нормами і правилами поведінки.

3 метою виявлення причин утруднень, що виникають під час реалізації принципу наступності в навчанні дітей дошкільного та молодшого шкільного віку використовуються «Анкета педагога дошкільного закладу та вчителя початкової школи» й анкета експерта «Забезпечення наступності в дошкільній та початковій ланках освіти», карти, опитувальники.

Для психолого-педагогічного, методичного забезпечення складових наступності педагоги-вихователі, вчителі нашого міста здійснили міський освітній проект «Партнерська взаємодія дошкільної й початкової ланок освіти 3 наступності». Розроблена система роботи рекомендацій із реалізації наступності між дошкільною та початковою ланками освіти.

Отже, наступність, будучи основною умовою переходу дитини від дошкільного навчального закладу до початкової школи, забезпечує неперервність освітнього простору дошкільників і молодших школярів, сприяє цілісному особистісному творчому розвитку кожної дитини, створює середовище для повної соціальної і особистісної життєдіяльності дитини, iї творчого розвитку, навчання, виховання, реалізації пізнавальних потреб протягом дошкільного дитинства і планового переходу до вищих освітніх ступенів.

\section{Література}

1. Амонашвили Ш. А. Здравствуйте, дети :[пособ. для учит.] / Ш. А. Амонашвили, предисл. А. В. Петровского. - М. : Просвещение, 1983. - 208 с. 2. Богуш А. М. Наступність, перспективність, спадкоємність - складові неперервної освіти / А. М. Богуш // Дошкільне виховання. - 2001. - № 11. - С. 11. 3. Венгер Л. А. Готов ли ваш ребенок к школе ? / Л. А. Венгер, А. Л. Венгер. - М. : Знание, 1994. - 192 с. 4. Гончаренко С. У. Український педагогічний словник / С. У. Гончаренко. - К. : Либідь, 1997. - С. 227.

УДК $378+378.4+06.06+001$

T. I. Койчева, кандидат пед.наук, дочент, Південноукраӥнський національний педагогічний університет імені К. Д. Уиинського

\section{НАУКОВІ ШКОЛИ ЯК ДЖЕРЕЛО РОЗВИТКУ КОРПОРАТИВНОЇ КУЛЬТУРИ ПЕДАГОГІЧНОГО УНІВЕРСИТЕТУ}

Койчева Т. І. Наукові школи як джерело розвитку корпоративної культури педагогічного університету.

У статті розглянуто сучасні інтерпретації феномену наукової школи, обгрунтовується ії роль в інноваційному розвитку вищого навчального закладу, формуванні i розвитку корпоративної культури педагогічного університету.

Ключові слова: наукова школа, педагогічний університет, корпоративна культура, інноваційний розвиток. 